\section{Peran Keluarga Sebagai Agen Sosialisasi dalam Meningkatkan Partisipasi Politik Wanita}

\author{
Oleh : F. Winarni
}

\section{Abstrak}

Potensi wanita Indonesia dalam kegiatan politik sangatlah besar dan merupakan aset bangsa yang tak ternilai harganya. Oleh karena itu perlu dibina, dikembangkan dan diberi kesempatan yang sama dengan laki-laki sebagai subyek dan obyek pembangunan.

Peningkatan partisipasi politik wanita dapat diupayakan melalui pemanfaatan peluang yang ada, baik yang sudah diatur dalam GBHN maupun lembaga-lembaga tingkat internasional yang menangani masalah wanita. Disamping itu perlu adanya redefinisi, reorientasi, dan sosialisasi politik agar lebih kondusif bagi pembinaan wanita dalam meningkatkan partisipasi politiknya pada khususnya dan semua warga negara pada umumnya.

Keluarga yang karena fungsi-fungsinya mempunyai peran penting sebagai agen sosialisasi politik bagi induvidu khususnya wanita untuk menanamkan nilainilai, sikap-sikap politik, orientasi politiknya baik secara langsung maupun tidak langsung. Proses sosialisasi politik dalam keluarga dilaksanakan dalam bentuk sosialisasi kognitig, afektif dan evaluatif. Besarnya peran keluarga dalam pelaksanaan sosialisasi politik sangat tergantung pada tingkat intensitas interaksi antara induvidu dengan keluarga, proses komunikasi yang berlangsung antara induvidu dengan keluarga, dan tingkat penekunan induvidu yang mengalami proses sosialisasi politik serta umur induvidu yang bersangkutan.

\section{Pendahuluan}

Kehidupan politik yang berlangsung di suatu negara sangatlah kompleks, mulai dar pembuatan keputusan, berfungsinya lembaga-lembaga politik, praktik-praktik politik dan sebagainya. Dalam analisis politik modern, partisipasi politik merupakan salah satu hal yang mendapat perhatian. Konsep ini populer sejak tahun 1960-an. $\mathrm{Ha}$ tersebut terlihat dari banyaknya sarjana ilmu politik yang menaruh perhatian pada studi partisipasi politik. Pentingnya studi dimensi politik terhadap proses partisipasi da likemukakan oleh Hutington dalam Black (1976) yang mengatakan bahwa "broadening political participations is a hallmark of politi cal modernization".

Studi partisipasi politik bila dikaitkan dengan wanita, ini membawa implikas bahwa wanita sebagai sosok yang patut diperhitungkan dan diteliti secara tersendir atau diperlakukan sebagai aktor atau subyek yang eksklusif dalam politik Meningkatnya kepedulian terhadap partisipasi politik wanitaa menunjukkan bahwa para ilmuwan dan para pengambil keputusan kini mulai menyadari bahwa persoalan pembangunan.

Oleh karena perannya sebagai aktor politik tersebut, maka cara berpikir, cara menuangkan ide-ide atau gagasan serta aktivitas wanita menjadi pusat perhatian baik pemerintah, kaum cendekiawan maupun lembaga-lembaga ilmu pengetahuan. Terlebih perhatian itu nampak dalam pembangunan dewasa ini yang memang mengharapkan peran serta wanita.

Bertolak dari pemahaman terhadap pentingnya keterlibatan wanita sebagai sumberdaya yang potensial untuk mencapai tujuan nasional, maka studi tentang partisipasi politik wanita menjadi urgen untuk dibahas. Yang menjadi permasalahan dalam tulisan ini adalah bagaimanakah partisipasi politik wanita di Lembaga Pemerintahan di Indonesia?; Faktor-faktor apakah yang mempengaruhi tingkat partisipai politik wanita, dan upaya-upaya apakah untuk meningkatkan partisipasi politik wanita di Indonesia?

\section{Pengertian Partisipasi Politik}

Berbicara tentang partisipasi poltik, tentu saja tidak dapat dihindarkan dari diskusi partisipasi politik menurut disiplin ilmu politik. Menurut Verba, Nie, dan Kim (1978:46, dalam Afan Gaffar, 1991) partisipasi politik adalah "legal activities by private citicens that are more or less directly aimed at influence the selection of governmental personnel and / or the actions they take".

Mely G. Tan (1992, dalam Yulfita, 1995:1) membedakan partisipasi politik dalam dua aspek, yaitu dalam arti sempit dan luas. Dalam arti sempit berupa keikutsertaan dalam politik praktis dan aktif dalam segala kegiatannya; sedangkan partisipasi politik dalam arti luas, berupa keikutsertaan secara aktif dalam kegiatan yang mempunyai dampak kepada masyarakat luas, mempunyai kemampuan, kesempatan dan kekuasaan dalam pengambilan keputusan yang mendasar yang menyangkut kehidupan oraang banyak.

Partisipasi politik dalam tulisan ini selanjutnya akan mengacu pada pengertian partisipasi politik dalam arti luas. Dengan demikian meliputi keterlibatan wanita secara aktif dalam kegiatan-kegiatan usaha penyelenggaraan negara daan pemerintahan dan mempunyai akses dalam pengambilan keputusan nasional.

Kiprah wanita Indonesia di kancah politik bukan hal yang baru. Dalam sejarah perjuangan kaum wanita Indonesia, banyak dijumpai tokoh-tokoh wanita seperti: R.A. Kartini, Dewi Sartika, Nyi Ageng Serang. Mereka memperjuangkan hak-hak wanita untuk dapat memperoleh pendidikan setara dengan pria. Di bidang lain ada wanita yang berjuang untuk merebut kemerdekaan seperti: Cut Nyak Dien, Maria Tiahahu, Yolanda Maramis dan sebagainya. Organisasi wanita telah lama ada sebelum kemerdekaan, bahkan tanggal 22 Desember 1928 mereka mengadakan konggres I. Kini di era pembangunan setelah kemerdekaan terdapat sekitar 66 unit organisasi wanita yang terhimpun dalam Kowani (Konggres Wanita Indonesia).

Secara legal UUD 1945 tidak membedakan laki-laki dan perempuan dan menjamin bagi warga negaranya persamaan hak dan kewajibannya di bidang politik dan lain-lainnya. Pada tahun 1978 persamaan hak, tanggung jawab dan kesempatan 
tersebut ditekankan secara eksplisit di dalam GBHN. Kepedulian Indonesia terhadap persamaan hak ini, juga tercermin dengan ikut sertanya menandatangani Konvensi mengenai penghapusan segala bentuk diskriminasi terhadap perempuan pada tahun 1980 dan diratifikasi tahun 1984 melalui UU No.7 tahun 1984.

Dari segi kuantitas, jumlah penduduk Indonesia berdasarkan hasil survai sosial ekonomi nasional (Susenas) tahun 1994 brjumlah Indonesia 192 juta. Dari jumlah tersebut persentase penduduk wanita sebesar 50,53 \% (BPS 1995). Jumlah yang besar tersebut walaupun telah mendapat pengakuan secara yuridis, namun dari berbagai data terlihat bahwa jumlah wanita yang aktif di bidang politik tidak mencerminkan jumlah yang besar.

Indonesia merupakan negara pertama di kawasan Asia-Pasifik yang membentuk kementrian yang secara khusus untuk meningkatkan peran perempuan. Berbagai kegiatan wanita telah muncul sejak pemerintahan Orde Baru baik organisasi profesi maupun Ikatan kerja suami, PKK, Kowani, BKOW, dan lain sebagainya. Hal tersebut menunjukkan adanya pertumbuhan partisipasi politik wanita semakin besar dan telah banyak membantu melaksanakan program-program pemerintah. Berbagai jabatan politis telah dicapai seperti menjadi menteri, anggota parlemen, ketua partai, camat, bupati, lurah, wakil ketua MPR, dan presiden. Di bidang aparatur negara, seperti menjadi pegawai negeri wanita juga telah banyak yang menduduki jabatan baik jabatan fungsional maupun struktural.

Berdasarkan data-data empirik seperti diuraikan di atas, dapat disimpulkan bahwa partisipasi politik wanita mengalami pertumbuhan, walaupun persentasenya masih relatif rendah di banding pria. Pertanyaan lebih lanjut yang perlu mendapat penjelasan adalah apakah motivasi wanita dalam ikut berpartisipasi di bidang politik?

\section{Motivasi Wanita dalam Kegiatan Politik}

Keterlibatan wanita dalam bidang politik tidak lepas dari berbagai kebutuhan yang ingin dipuaskan oleh wanita yang menuntut untuk dipenuhi. Hal ini sesuai dengan apa yang dikatakan oleh Miftah Thoha (1989:45) bahwa perilaku seseorang itu disebabkan oleh oleh adanya beberapa faktor. Adakalanya perilaku seseorang dipengaruhi oleh kemampuannya, ada pula karena kebutuhannya dan ada juga yang dipengaruhi oleh pengharapan dan lingkungan.

Perilaku wanita dalam kegiatan politik mempunyai karakteristik yang berbeda antara wanita satu dengan lainnya bila dilihat dari segi pendidikan, pengalaman, kepribadian, sikap maupun status sosialnya. Hal yang menjadi dorongan seseorang atau alasan untuk berperilaku atau bersikap tertentu, dalam teori manajemen disebut motivasi.

Dari pendapat beberapa ahli seperti: Anderson, Clelland dan Cover dapat diambil kesimpulan bahwa motivasi adalah kecenderungan organisme untuk melakukan sesuatu yang dipengaruhi oleh kebutuhan dan diarahkan kepada pencapaian tujuan tertentu yang direncanakan. Namun ada pula yang mengartikan motivasi sebagai pembinaan atau pemupukan agar seseorang mempunyai motive yang tinggi atau mempunyai kecenderungan seperti di atas.

Dari pengertian di atas, motivasi mempunyai empat unsur, yaitu: kecenderungan melakukan sesuatu, kebutuhan, tujuan dan perencanaan. Kecenderungan melakukan suatu berarti terdapat keinginan kuat untuk melakukansesuatu, misal: ingin mencapai prestasi yang tinggi, menjadi public figure, menjadi pengurus parpol dan sebagainya. Kebutuhan merupakan sesuatu yang mendasari terjadinya kecenderungan tersebut, yang dapat diklasifikasikan dalam kebutuhan jasmaniah, rohaniah, sosial dan sebagainya. Tujuan merupakan arah perilaku untuk memenuhi kebutuhan yang memungkinkan terjadinya kecenderungan. Sedangkan perencanaan merupakan kegiatan yang memungkinkan kecenderungan itu dapat mencapai tujuan secara efektif dan efisien.

Motive merupakan daya penggerak atau dorongan untuk berbuat. Jika seseorang mempunyai kebutuhan, maka ia akan terdorong untuk berbuat memenuhi kebutuhan tersebut. Tetapi tidak selamanya arah kecenderungan untuk berbuat itu karena suatu kebutuhan, sering kali dorongan itu perlu dibangkitkan, baik oleh orang lain juga oleh dirinya sendiri dengan penghayatan memahami arti pentingnya, membiasakan sesuatu dan melihat masa depan.

Pengertian motivasi menurut Wahjo Sumidjo (1987:171) adalah dorongan atau kemauan yang datangnya dari dalam diri seseorang untuk melaksanakan aksi tertentu yang diinginkan. Kamus Besar Bahasa Indonesia (1997:593) memberikan pengertian motivasi sebagai dorongan yang timbul pada diri seseorang sadar atau tidak untuk melakukan sesuatu tindakan dengan tujuan tertentu, usaha-usaha yang dapat menyebabkan seseorang atau kelompok orang tertentu tergerak melakukan sesuatu hal karena ingin mencapai tujuan yang dikehendaki atau mendapat kepuasan dengan perbuatannya.

Berbicara tentang motivasi wanita dalam kegiatannya berpolitik, maka hal pokok yang menjadi bagian dari pembicaraan adalah faktor-faktor apakah yang menjadi pendorong wanita melibatkan diri dalam politik. Tujuan pembicaraan antara lain ingin menjawab persoalan "motivasi apakah yang mempengaruhi tingkat partisipasi politik wanita dalam lembaga-lembaga pemerintahan."

Hasil-hasil penelitian menemukan bahwa banyak faktor yang mempengaruhi motivasi seseorang untuk memilih suatu aktivitas tertentu khususnya aktivitasnya dalam bidang politik. Faktor-faktor tersebut dapat berasal dari dalam induvidu dan dari luar induvidu (motivasi intrinsik dan motivasi ekstrinsik). Apabila ditinjau dari segi kebutuhan manusia secara umum, dikemukakan suatu teori tentang kebutuhan yang sangat klasik yaitu teori Abraham Maslow. Menurut Maslow (1954:370) kebutuhan manusia dapat diklasifikasikan menjadi lima kelompok yaitu:
1.
Safety Needs
3. Social Needs
4. Self Esteem Needs
5. Self Actualization Needs 
Physical Needs atau kebutuhan fisik merupakan kebutuhan biologis seperti pangan, sandang, papan, sex. Safety Needs atau kebutuhan keamanan, seperti rasa aman dari bahaya, perlindungan hukum dan perlindungan moral. Social Needs atau kebutuhan sosial, seperti rasa diterima, bersahabat dan dicintai. Self Esteem Needs atau kebutuhan akan harga diri, yang pada umumnya terwujud dengan perasaan ingin dihargai, keinginan untuk mempunyai kekuasaan dan kemuliaan. Self Actualization Needs atau kebutuhan akan aktualisasi diri yaitu kebutuhan untuk bisa mengembangkan diri dalam seluruh aspek kepribadian secara optimal.

Menurut teori kebutuhan yang dikemukakan oleh Abraham Maslow in dalam kehidupannya, manusia akan memenuhi kebutuhan sesuai dengan urutan kepentingannya. Akan tetapi kenyataannya kebutuhan orang berbeda-beda karena adanya beberapa faktor yang mempengaruhinya, yaitu antara lain latar belakang pendidikan, pengaruh masa lalu, cita-cita atau harapan masa depan, dan pandangan seseorang sehingga jenjang kebutuhan itu akan berbeda antara orang yang satu dengan lainnya.

Mc. Clelland mengemukakan tiga macam motivasi sosial, yaitu: (1) motivasi berprestasi (need for achievement), (2) motivasi berkuasa (need for power), dan (3) motivasi berafiksasi (need for affiliation). Ke tiganya saling berkaitan didalam perilaku sosial manusia.

Berdasarkan uraian di atas dapatlah diambil kesimpulan bahwa motivasi pada dasarnya berkaitan dengan faktor psikologis seseorang yang mencerminkan hubungan atau interaksi antara sikap, kebutuhan dan kepuasan yang terjadi pada diri manusia. Dengan demikian berbagai konsep dan teori motivasi tersebut dapa memberikan sumbangan masing-masing untuk mengkaji lebih lanjut mengenai faktor motivasi wanita dalam kegiatan politiknya. Orang yang mempunyai motivasi yang kuat akan membuatnya tidak lekas putus asa, pantang mundur, mau belajar dan bekerja keras.

\section{Kendala-Kendala Partisipasi Politik Wanita}

Untuk terlibat baik mental maupun emosi wanita dalam segala aspek kegiatan politik tidaklah mudah. Kondisi wanita Indonesia yang dicapai sekarang ini terbentuk oleh adanya kendala yang menghambat partisipasi politiknya. Kendala pokok yan seringkali dipergunakan sebagai alasan lemahnya partisipasi politik wanita, dapa dikelompokkan menjadi dua yaitu: hambatan internal dan hambatan eksternal.

Hambatan internal, berupa keengganan sebagian besar wanita untuk terlibat dalam kegiatan politik. Keengganan ini dikarenakan sosio-kultural mereka yang belum memungkinkan bisa aktif menyuarakan, dan menyampaikan keinginan-keinginan di bidang politik. Aktivitas politik dianggap tidak layak untuk perempuan, karena sifat-sifat yang berjauahan dari citra untuk wanita. Dunia politik dianggap "keras", "kotor", "main kayu", dan penuh muslihat sehingga dianggap tidak cocok untuk citra wanita. Pandangan ini membuat dunia politik itu bias laki-laki, bahkan dianggap tabu untuk wanita. Konsekuensi lebih lanjut wanita menjadi enggan memasukinya Wanita menjadi pasif dalam berpolitik.

\section{INFORMASI}

Lingkungan sosial budaya yang kurang mendukung pengembangan potensi wanita, antara lain wawasan orang tua, adat, penafsiran terhadap ajaran agama yang tidak tepat, tingkat pendapatan keluarga, dan sistem pendidikan yang diskriminatif. Masih lekatnya budaya tradisional dan kecilnya akses wanita pada penguasaan faktor sosial ekonomi, menyebabkan terbentuknya image dalam diri wanita bahwa memang sewajarnya mereka berada di belakang pria.

Kendala eksternal menurut Afan Gaffar (1991:25) antara lain dari birokrasi yang paternalistik, pola pembangunan ekonomi dan politik yang kurang seimbang dan kurang berfungsinya partai politik. Dari beberapa kendala yang menghambat partisipasi politik wanita tersebut, tulisan ini membataskan diri pada upaya pemecahan terhadap kendala intern.

\section{Upaya Peningkatan Partisipasi Politik Wanita}

Peningkatan peran serta wanita dalam bidang politik, perlu pemahaman dan analisis menyeluruh sehingga dihasilkan suatu rekomendasi kebijakan yang tepat. Beberapa peluang bagi wanita untuk dapat meningkatkan kualitas perannya di bidang politik antara lain:
1. Pasal 17 dan 21 UUD 1945
2. GBHN sejak tahun 1978
3. Konferensi-Konferensi Wanita se-dunia

Peluang-peluang yang mendukung tersebut, memang pada akhirnya akan dikembalikan kepada wanita untuk memanfaatkannya atau tidak. Namun bila mengingat besarnya potensi yang ada pada wanita Indonesia yang secara kuantitas lebih besar daripada pria, maka sewajarnya bila peluang dan potensi tersebut tidak disia-siakan.

Wanita dalam pengembangan kiprahnya sebagai warganegara, mempunyai harapan sebagai pemilik masa depan bangsa, yang secara fungsional harus mampu menempatkan diri sebagai pemimpin tenaga pembaharu, dinamisator dan katalisator untuk pembangunan nasional. Oleh karena itu wanita dalam menghadapi tantangan abad XXI, harus mampu membekali dirinya dengan ilmu, teknologi dan berbagai macam kemampuan dan ketrampilan di berbagai kehidupan seperti politik, ekonomi, sosial dan budaya bangsanya.

Upaya untuk mengentaskan ketidakberdayaan wanita yang berkaitan dengan kualitas perannya di bidang politik, yang pertama adalah menghilangkan segala bentuk diskriminasi terhadap wanita di pentas politik untuk mengaktuaisasikan kemampuannya. Hal tersebut tidak hanya selaras dengan tujuan pembangunan nasional, tetapi juga karena jumlah wanita Indonesia adalah separo jumlah penduduk Indonesia. Oleh karena itu sangatlah wajar bila ada wakil yang dapat menyuarakan aspirasi politik wanita.

Peran wanita Indonesia di pentas politik sudah waktunya mendapat pors yang proporsional. Seyogyanya tidak ada lagi ucapan yang meragukan kemampuannya untuk tampil di pentas politik. Oleh karena itu harus ada gerakan 
yang mendorong terwujudnya kebijakan pemerintah yang memiliki kepekaan gen der. Untuk mencapai keberhasilan gerakan tersebut, memerlukan akses wanita terhadap pembuatan keputusan nasional. Hal tersebut sesuai pernyataan senator Leticia Ramos Shahani, ketua delegasi Philipina pada Konferensi k-empat PBB mengenai wanita bahwa " akses terhadap pembuatan keputusan sangatlah penting bagi siapapun yang menghendaki reformasi untuk memasukkan dunia politik bagi wanita." (Angkatan Bersenjata, 14 September 1995)

Dari sisi keberanian wanita, perlu upaya penyadaran terhadap wanita bahwa pola struktural hubungan laki-laki dan perempuan yang terbangun selama ini harus dirombak. Perombakan tersebut bukan hanya pada level gagasan atau ideologi, tetapi juga dalam praktek di mana tampak dengan kentara perlakauan yang sama terhadap hak-hak asasi kaum wanita di bidang sosial, politik, ekonomi, kebudayaan, dan dalam lingkungan keluarga. Dengan demikian pola pemikiran dominasi laki-laki yang selama ini mengakar dalam kehidupannya perlu dirubah, dan diwujudkan dalam kemitrasejajaran. Tradisi masa lalu yang selama ini memandang wanita sebagai warga masyarakat "kelas dua" mesti ditinggalkan dan diganti pemikiran kesetaraan.

Pandangan teologis yang mengatakan bahwa pria dan wanita diciptakan dalam keberadaan yang sama, saling melengkapi yang satu dengan yang lainnya harus diwujudkan dalam konteks makro dan mikro. Maksudnya dalam lingkup bangsa dan negara di bidang sosial, politik, ekonomi, dan budaya kaum wanita harus dipandang setara dengan kaum laki-laki (skala makro). Dalam lingkup yang lebih sempit (mikro) yakni dalam hubungan suami isteri, kesetaraan itu diwujudkan secara adil, yakni adanya pengakuan dari suami bahwa isteri adalah subyek pertama juga. Pekerjaan yang selama ini didelegasikan kepada isteri secara domestik mestinya juga bisa dikerjakan oleh kaum suami.

Upaya menuju ke arah cita-cita kesetaraan ini memang tidak mudah bahkan rumit, banyak tantangan dan hambatan. Upaya tersebut memerlukan keterlibatan semua pihak yakni kaum wanita sendiri, kaum laki-laki dan unsur kebijakan nasional yang berwawasan gender. Proses penyadaran harus dilakukan secara simultan di kalangan baik laki-laki maupun perempuan. Karena kalau tidak maka jalan pencerahan yang ditempuh wanita akan berbenturan dengan kaum laki-laki yang merasa kekuasaannya akan ditumbangkan.

Proses penyadaran terhadap sikap-sikap, norma-norma, nilai-nilai ataupun kepribadian dikenal dalam konsep sosiologi sebagai sosialisasi. Dikatakan oleh Rose dan Glazer bahwa "sosialization is the process of learning the belief, value, norms and social roles of a culture and society" (1977:273). Bertolak dari pengertian tersebut maka proses penyadaran kaum wanita untuk memahami hak dan kewajibannya di bidang politik, disebut sosialisasi politik. Dennis Kavanagh mempergunakan istilah tersebut untuk menggambarkan proses dengan jalan mana orang belajar tentang politik dan mengembangkan orientasi pada politik (1982:367)

Bertolak dari pengertian tersebut, maka proses penyadaran kaum wanita untuk memahami hak dan kewajibannya di bidang politik mempunyai dua perspektif, yaitu perspektif pengajaran dan perspektif belajar. Pada perspektif pengajaran, obyek sosialisasi bertindak pasif, sasaran hanya dilihat sebagai obyek yang menerima apa

INFORMASI adanya dari agen sosialisasi, dengan kata lain ia dibentuk oleh sistem politik. Sedangkan dalam perspektif belajar, sasaran dilihat sebagai pihk yang berinisiatif. la berperan aktif untuk menginternalisir nilai-nilai, keyakinan-keyakinan yang ia saring dari dunia politik di sekitarnya secara langsung.

Sosialisasi politik dapat dilaksanakan secara langsung dan dapat secara tidak langsung. Dikatakan langsung apabila sikap-sikap dan tingkah laku yang dipelajari dan diwariskan kepada induvidu itu secara eksplisit bersifat politis. Sedangkan dinamakan tidak langsung apabila nilai-nilai sikap-sikap dan pola-pola tingkah laku itu tidak secara eksplisit bersifat politis, tetapi nilai-nilai itu akan mempengaruhi sikap dan pandangan politik induvidu di kelak kemudian hari. Pelaksanaan sosialisasi politik dapat terjadi melalui beberapa sarana atau wahana, antara lain menurut Gabriel Almond dalam Haryanto (1982:39): keluarga, sekolah, kelompok bergaul atau bermain, pekerjaan, media massa dan kontak politik. Tulisan ini membatasi pada uraian sosialisasi politik tidak langsung melalui wahana keluarga

\section{Keluarga sebagai Agen Sosialisasi Politik}

Keluarga disepakati menempati posisi sentral dalam proses sosialisasi politik, di samping sekolah. Keluarga telah lama diakui dan dianggap sebagai agen sosialisasi politik yang paling penting dan paling awal (Stephen Douglas, 1970:25). Posisi sentral dari keluarga pada dasarnya memang sesuai dengan fungsi keluarga yakni : fungsi biologik, fungsi afeksi dan fungsi sosialisasi. Alasan lain dari pentingnya kedudukan keluarga dalam proses sosialisasi politik yakni:

Pertama, keluarga merupakan institusi pertama yang ditemui oleh induvidu. Dalam keluargalah induvidu pertama mulai belajar berinteraksi dengan orang lain (orang tua) dan mengenal pola hubungan kekuasaan. Pola hubungan kekuasaan dalam keluarga ini akan mempengaruhi jiwa induvidu dan lebih lanjut akan mempengaruhi persepsinya terhadap pola hubungan kekuasaan dalam konteks yang lebih luas, antara lain dalam sistem politik.

Kedua, keluarga merupakan institusi pertama dimana induvidu menerima nilai-nilai, sikap-sikap, norma-norma dan pola-pola tingkah laku dalam upayanya menjadi anggota kelompok dan anggota masyarakat yang baik. Termasuk di dalamnya menerima nilai-nilai dan sikap-sikap politik induvidu yang nantinya akan mempengaruhi pola tingkah laku politiknya.

Ketiga, hubungan dalam keluarga lebih bersifat emosional sehingga pengaruhnya terhadap induvidu lebih berarti atau bermakna dan tahan lama daripada daripada hubungan yang sifatnya intelektual dalam proses sosialisasi. Hal tersebut seperti dikemukakan oleh Almond bahwa pengaruh kehidupan keluarga baik yang langsung maupun tidak langsung - dimana merupakan struktur sosialisasi pertama yang dialami seseorang - sangat kuat dan kekal (ibid, h.37). Kuatnya pengaruh keluarga itu disebabkan nilai yang diperoleh induvidu dalam keluarga adalah merupakan nilai 
dasar yang pertama, sebelum berhubungan dengan dunia luar. Nilai dan sikap ini akan mengendap dalam dirinya dan tidak akan mudah berubah meskipun nantinya ia akan menerima pengaruh lainnya dari luar lingkungan keluarga.

Dalam melaksanakan fungsinya sebagai wahana sosialisasi politik, keluarga dapat mewariskan nilai-nilai yang secara eksplisit bersifat politis, juga dapat pula mewariskan nilai-nilai yang secara tidak eksplisit bersifat politis, tetapi nantinya akan berpengaruh terhadap sikap dan pandangan politik induvidu. Pada gilirannya sikap dan pandangan ini akan mempengaruhi pula tingkah laku politiknya. Sosialisasi politik melalui keluarga dapat memberikan pengaruh bagi seorang induvidu untuk bisa mengenal sistem politik, yang kemudian menentukan sifat persepsi-persepsinya mengenai politik serta reaksi-reaksinya terhadap gejala-gejala politik. Hal tersebut ditegaskan oleh Almond yang mengatakan bahwa proses sosialisasi politik akan membentuk nilai-nilai politik, yang menunjukkan bagaimana seharusnya masingmasing anggota masyarakat berpartisipasi dalam sistem politik.

Proses sisialisasi politik menurut Herbert M. Levine (1982) dapat dibedakan dalam tiga tipe yakni: cognitive socialization, affective socialization, evaluative socialization. Sosialisasi kognitif yaitu bagaimana pengetahuan mengenai struktur dasar dan kaidah-kaidah politik diterima induvidu. Sosialisasi afektif menyangkut bagaimana proses induvidu mengembangkan rasa persetujuan atau penolakannya terhadap pemimpin politik, unit pemerintahan atau sistem politik. Sosialisasi evaluasi evaluatif berkaitan dengan proses melalui mana seseorang menerima pertimbanganpertimbangan dan pendapat-pendapat mengenai sistem politik yang didasarkan pada beberapa kriteria moral.

Pelaksanaan sosialisasi politik dilakukan melalui wahana (agen). Wahanawahana itu menurut Almond seperti dikemukakan di muka adalah keluarga, sekolah, kelompok bermain atau bergaul, pekerjaan, media massa dan kontak-kontak politik langsung. Besarnya pengaruh atau peranan dari wahana-wahana tersebut menurut Haryanto (1982:33) tergantung pada tingkat intensitas interaksi antara induvidu dengan wahana yang ada, proses komunikasi yang berlangsung antara induvidu dengan wahana tadi, dan tingkat atau derajat penekunan induvidu yang mengalami proses sosialisasi politik serta umur induvidu yang bersangkutan.

Salah satu hal yang dipandang penting dalam sosialisasi politik melalui keluarga dapat mempengaruhi partisipasi politik seseorang. Nilai ini dipandang penting dalam mempengaruhi tindak tanduk atau perilaku politik anak setelah menginjak dewasa. Hal tersebut ditandaskan oleh Stephen Douglas (1970:46)

\section{Penutup.}

Berdasarkan uraian pembahasan di atas, maka dapat ditarik kesimpulan uraian sebagai berikut:

1. Potensi sumberdaya wanita Inddonesia sangatlah besar dan merupakan aset bangsa yang tak ternilai harganya yang perlu dibina, dikembangkan dan diberi kesempatan yang sama dengan laki-laki sebagai subyek dan obyek pembangunan.

2. Secara yuridis formal Indonesia tidak membedakan antara laki-laki dan wanita

\section{INFORMASI}

dalam bidang politik. Namun karena kendala baik yang bersumber dari intern wanita itu sendiri maupun faktor ekternal, maka partisipasi politik wanita secara kuantitatif jauh lebih rendah dibanding partisipasi politik laki-laki.

3. Peningkatan partisipasi politik wanita dapat diupayakan melalui pemanfaatan peluang yang ada, baik yang sudah diatur dalam GBHN maupun lembaga-lembaga tingkat internasional yang menangani masalah wanita. Disamping itu perlu adanya redefinisi, reorientasi, dan sosialisasi politik agar lebih kondusif bagi pembinaan wanita dalam meningkatkan partisipasi politiknya pada khususnya dan semua warga negara pada umumnya.

4. Keluarga yang karena fungsi-fungsinya mempunyai peran penting sebagai agen sosialisasi politik bagi induvidu khususnya wanita untuk menanamkan nilai-nilai, sikap-sikap politik, orientasi politiknya baik secara langsung maupun tidak langsung. Proses sosialisasi politik dalam keluarga dilaksanakan dalam bentuk sosialisasi kognitig, afektif dan evaluatif.

5. Besar kecilnya pengaruh atau peran keluarga dalam pelaksanaan sosialisasi politik yang nantinya dapat meningkatkan partisipasi politik wanita pada khususnya, tergantung pada tingkat intensitas interaksi antara induvidu dengan keluarga, proses komunikasi yang berlangsung antara induvidu dengan keluarga, dan tingkat atau derajat penekunan induvidu yang mengalami proses sosialisasi politik serta umur induvidu yang bersangkutan

\section{Daftar Pustaka}

Afan Gaffar. 1991. "Partisipasi Politik di Indonesia", Prospektif . No.1 Vol.3.

Daryanto. 1997. Kamus Besar Bahasa Indonesia. Surabaya: Apollo.

Douglas, Stephen. 1970. Political Socialization and Student Activism In Indonesia. University of Illinois Press.

Haryanto 1982. Sistem Politik: Suatu Pengantar. Yogyakarta: Liberty.

Herbert M. Levine 1982. Politicial Issues Debated an Introduction to Politics. New Jersey: Prentice-Hall Inc, Englewood Cliffs.

Hutington, Samuel, "The Change to Change Modernization, Development, and Politics," dalam Cyril E. Black (ed). 1976. Comparative Modernization: A Reader. New York: The Free Press.

Kavanagh, Dennis. 1982. Kebudayaan Politik. Jakarta: Bina Aksara.

Maslow, A.H. 1954. Motivation and Personality. New York: Harper \& Row. 
Miftah Thoha .1989. Perilaku Organisasi. Jakarta: Rajawali Press.

Rose, I. Peter dan Myron Glazer \& Peninan Migdal Glazer. 1977. Sociology: Inquiring Into Sociaty. San Francisco: Canfield Press.

Wahjo Sumidjo. 1987. Kepemimpinan dan Motivasi. Jakarta: Ghalia Indonesia.

Yulfita Raharjo. 1995. "Konsepsi Pembangunan politik: Perspektif Gender", Makalah Seminar Nasional : Peran Wanita dalam Pembangunan Sosial Budaya Politik Bangsa. Yogyakarta: Biro Bina DPD Golkar Tk I, Propinsi DIY.

\section{Biodata Penulis}

F. Winarni, Lahir 19 Januari 1959. Pendidikan S1 dan S2 di tempuh di FISIPOL UGM Yogyakarta dengan bidang studi IImu Administrasi Negara. Tahun 1987 sampai sekarang menjadi Tenaga Akademik pada FIS UNY dengan jabatan Lektor Kepala.

\section{Pengembangan Hukum Tertulis dalam Uud 1945 \\ Beserta Arti Penting Amandemen Uud 1945 di Bidang Pemerintahan Daerah}

\author{
Oleh : Eny Kusdarini
}

\section{Abstrak}

UUD 1945 merupakan konstitusi/hukum dasar tertulis bangsa Indonesia yang ada sejak Indonesia merdeka. Selama ini, apalagi pada masa Orde Baru keberadaan UUD 1945 disakralkan dan dikatakan dengan sifatnya yang singkat, supel, dan luwes mampu mengahadapi perkembangan zaman sehingga sampai dengan jatuhnya Orde Baru belum pernah ada perubahan walaupun sebetulnya alasan itu hanya dipakai untuk kepentingan penguasa negara. Setelah jatuhnya Orde Baru ada berbagai tuntutan dari masyarakat untuk merubah tatanan kehidupan berbangsa dan bernegara terutama tatanan hubungan antara pemerintah pusat dan pemerintah daerah. Tuntutan-tuntutan dari berbagai kalangan masyarakat tersebut ditindaklanjuti dengan adanya amandemen terhadap UUD 1945. Terlepas dari pro dan kontra terhadap prosedur dan tata cara perubahan terhadap UUD Negara Republik Indonesia, maka terjadilah pengembangan hukum tertulis yang tertuang di dalam UUD 1945 dan pengembangan hukum tertulis tersebut mempunyai arti yang sangat penting dalam bidang ketatanegaraan termasuk berubahnya kelembagaan negara dan perubahan di bidang pemerintahan daerah di Indonesia. Pengembangan hukum dalam UUD 1945 membawa perubahan penyelenggaraan pemerintahan di Indonesia yang pada awalnya bersifat sentralistik ke pemerintahan yang bersifat desentralistik.

\section{Pendahuluan}

Perubahan tatanan kehidupan masyarakat yang terjadi pada saat ini merupakan fenomena baru yang terjadi secara terus menerus menuju kepada kemajuan jaman. Globalisasi yang dipicu dengan adanya kemajuan teknologi di berbagai bidang berkembang sangat cepat tidak mengenal batas wilayah, ruang, dan waktu serta berpengaruh hampir di dalam semua aspek kehidupan manusia. Perubahan tersebut mempengaruhi kehidupan manusia baik secara individu maupun kelompok masyarakat, termasuk di dalamnya organisasi masyarakat, organisasi sosial, organisasi negara, dan tidak ketinggalan pula negara Indonesia.

Menurut Satjipto Rahardjo (1979, hal : 25), perubahan hukum (termasuk di dalamnya amandemen UUD 1945) dipengaruhi oleh perubahan masyarakat. Dimensi perubahan merupakan fenomena yang mengarah pada penyempurnaan perlindungan pengaturan dengan memperhatikan perubahan masyarakat. Masyarakat akan terus dituntut untuk melakukan perubahan di segala bidang. Dengan adanya kemajuan 